\title{
Kesiapan Tenaga Kerja Indonesia yang Tidak Memiliki Keterampilan (Unskill) dalam Menghadapi ASEAN Community 2015
}

\author{
Nur Afni, Restu Rahmawati \\ Universitas 17 Agustus 1945 Jakarta \\ restu.rahmawati3@gmail.com
}

\begin{abstract}
Indonesia is the most populous country in South East Asia. Indonesia's population growth continues to increase from year to year so that the total labor force also increased. This raises the employment problem in the absence of a balance between labor and Bid in negeri.Akan commencement Asean Community in 2015 will provide a positive and negative impact for Indonesia. Liberalism free market of goods and services will spur domestic investment and attracted foreign workers to Indonesia. The influx of foreign workers in Indonesia can be a threat if possible Indonesian workers do not have a comparable competitiveness. Rights for workers in Indonesia have been set in both the 1945 constitution, the Law No. 39 Year 2004 on Human Rights, and the Act No. 13 of 2003 on Manpower.
\end{abstract}

Keywords: Indonesian labor unskill,Asean Community 2015

\begin{abstract}
ABSTRAK
Indonesia adalah Negara dengan jumlah penduduk terbanyak di Asia Tenggara.Pertumbuhan penduduk Indonesia terus meningkat dari tahun ketahun sehingga jumlah angkatan kerja juga terus meningkat. Hal tersebut menimbulkan masalah ketenagakerjaan karena tidak adanya keseimbangan antara permintaan dan penawaran tenaga kerja dalam negeri.Akan dimulainya

Community asean 2015 akan memberikan dampak positif dan negative bagi Indonesia.

Liberalisme pasarbebas barang dan jasa akan memacu investasi dalam negeri dan menarik tenaga kerja asing ke Indonesia. Masuknya tenaga kerja asing ke Indonesia dimungkinkan dapat menjadi ancaman apabila tenaga kerja Indonesia tidak mempunyai daya saing yang sebanding. Hak-hakasasi bagi para tenaga kerja di Indonesia telah diatur dalam konstitusi baik dalam UUD 1945, Undang-Undang Nomor 39 Tahun 2004 tentang Hak Asasi Manusia, maupun dalam Undang-Undang Nomor 13 tahun 2003 tentang Ketenagakerjaan.
\end{abstract}

Kata Kunci :Tenaga kerja tidak memiliki ketrampilan, Asean Community 2015

\section{Latar Belakang}

Indonesia adalah negara dengan jumlah penduduk terbanyak di Asia Tenggara. Pertumbuhan penduduk Indonesia terus meningkat dari tahun ke tahun sehingga jumlah angkatan kerja juga terus meningkat. Hal tersebut menimbulkan masalah ketenaga kerjaan karena tidak adanya keseimbangan antara permintaan dan penawaran tenaga kerja dalam negeri.Akan dimulainya Asean Community 2015 akan memberikan dampak positif dan negatif bagi 
Indonesia. Liberalisme pasar bebas barang dan jasa akan memacu investasi dalam negeri dan menarik tenaga kerja asing ke Indonesia.

Masuknya tenaga kerja asing ke Indonesia dimungkinkan dapat menjadi ancaman apabila tenaga kerja Indonesia tidak mempunyai daya saing yang sebanding. Oleh karena itu, peningkatan daya saing tenaga kerja harus dilakukan jauh hari sebelum MEA(Masyarakat Ekonomi Asean) 2015 benar-benar dimulai. Hal tersebut dapat di antisipasi dengan mengkorelasikan input penunjang tenaga kerja sehingga tenaga kerja Indonesia memiliki kesiapan mental dan kemampuan agar kesiapan tenaga kerja Indonesia dalam menghadapi Asean Community 2015 lebih matang dan memiliki daya saing yang tinggi dari negara lainnya.

Indonesia adalah negara yang kaya akan sumber daya baik sumber daya alam maupun sumber daya manusia. Berbeda dengan sumber daya alam yang jumlahnya terbatas dan cenderung jumlahnya semakin berkurang., sumber daya manusia jumlahnya terus meningkat.Di era globalisasi seperti ini, tentu banyak negara yang saling bekerjasama. Hal ini pula yang terjadi dengan negara-negara yang tergabung dalamASEAN (Association of Southeast Asian Nations). Kesiapan tenaga kerja serta pemerintah Indonesia yang menjadi tolak ukur dalam menghadapi Asean community 2015. Dalam sumber daya manusia di Indonesia yang di lihat memiliki daya saing pada sumber daya manusia, dalam hal ini kesiapan yang terlihat hanya pada tenaga kerja yang sudah memiliki pengalaman pada bidangnya maupun Tenaga kerja Indonesia yang tidak memiliki ketrampilan(unskill) menjadi persoalan utama negara ini banyak peristiwa yang mengakibatkan bencana kemanusiaan pada tenaga kerja Indonesia di luar negeri karna disebabkan oleh kurangnya ketrampilan(unskill) serta pengalaman dalam menghadapi kondisi serta keadaan pada saat terjun di lapangan pekerjaan.kurangnya pengetahuan serta ketrampilan yang menjadi alasan utama penyebab permasalahan pada tenaga kerja Indonesia saat ini.

Berdasarkan latar belakang diatas yang menjadi perumusan masalah dalam skripsi atau penelitian ini adalah Bagaimana kesiapan tenaga kerja Indonesia dalam menghadapi Asean Community 2015? Dan Langkah-langkah apa yang telah di lakukan pemerintah Indonesia dalam menghadapi Asean Community 2015 pada Tenaga Kerja yang tidak memiliki ketrampilan(unskill)?

\section{Pembahasan}

Pada mulanya wawasan ASEAN disepakti terwujud pada tahun 2020 akan tetapi setalah berbagi pertimbangan dari negara-negara anggota disepakati percepatan pembentukan Komunitas 
ASEAN dari 2020 menjadi 2015 oleh para Kepala Negara ASEAN pada KTT ke-12 ASEAN sebagai wukud dari piagam ASEAN (ASEAN Charter) yang ditanda tangani di KTT ASEAN ke13 di Singapura, 20 November 2007. Dalam kerangka kerjasama regional ASEAN, isu pekerja migran merupakan salah satu yang paling krusial dan masih dalam pembahasan yang cukup mendalam dalam rangka menyongsong terwujudnya komunitas ASEAN pada 2015, ASEAN seyogyanya menjadi kawasan yang ramah bagi para pekerja migran dan menjadi komunitas yang dapat memberi keuntungan kepada pahlawan devisa tersebut, karena fenomena pergerakan pekerja migran di dalam baik bagi negara pengirim, maupun Negara penerima.Melalui jalan perundingan, sejauh ini negara-negara anggota ASEAN telah berkomitmen untuk melakukan kerjasama dan upaya konsensus dalam penanganan isu pekerja migran di dalam kawasan, dengan berbagai tantangan dan hambatan yang tentunya tidak sedikit. Sebuah terobosan penting terjadi pada KTT ASEAN ke-12 tahun $2007^{1}$ di Cebu yang telah mengesahkan suatu deklarasi mengenai perlindungan dan promosi peningkatan terhadap hak-hak para pekerja migran yang sejalan dengan visi ASEAN dalam membangun suatu masyarakat ASEAN yang adil, manusiawi dan demokratis. Guliran selanjutnya dilakukan pada pertemuan ke-40 ASEAN Foreign Ministers Meeting (AMM), Manila, Juli 2007 yang sepakat untuk membentuk ASEAN Committee on the Implementation of the Declaration on the Protection and Promotion of the Rights of Migrant Workers (ACMW). Komite ini dimaksudkan untuk menjadi vocal point dalam mengkoordinasikan upaya-upaya untuk menjamin implementasi dari komitmen yang tertuang dalam deklarasi serta memfasilitasi upaya pembentukan ASEAN Instrument on the Protection and Promotion of the Rights of Migrant Workers. Melalui usulan Indonesia, telah disepakati pembentukan suatu Forum on Migrant Workers yang akan bertugas menindaklanjuti deklarasi dengan memanfaatkan kelompok kerja pada pertemuan ke-2 Ad-Hoc Working Group on Labour Practices to Enhance Competitiveness di Singapura tanggal 1-2 Maret 2007.Pada pertemuan ke-3 Ad-Hoc Working Group on Progressive Labour Practice, di Yogyakarta tanggal 9-10 September 2007, antara lain telah disepakati bahwa Filipina akan menyusun TOR Forum sebagai rujukan dalam pembentukan dan pelaksanaan kegiatan dalam membahas penanganan isu migrant workers. Dalam kaitan ini, pertemuan pertama ASEAN Forum on Migrant Labour di Filipina tanggal 24-25 April 2008 telah menyepakati untuk menyelenggarakan forum tersebut secara regular dan sepakat untuk menjadwalkan pertemuan ASEAN Committee on the Implementation of the Declaration on the Protection and Promotion of the Rights of Migrant Workers (ACMW) serta menyusun struktur dan fungsi Komite dimaksud sebelum KTT ke-14 tahun 2008.

\footnotetext{
${ }^{1}$ http//id.wikipedia.org//wiki/wawasan_2020_asean.
} 
Pertemuan ke-1 ACMW di Singapura tanggal 15-16 September 2008 telah membahas Work Plan dari komite dalam membentuk instrumen ASEAN dalam rangka implementasi ASEAN Declaration on the Protection and Promotion of the Rights of Migrant Workers. Pertemuan juga menyepakati pembentukan kelompok perumus yang terdiri dari empat negara (Thailand, Indonesia, Malaysia dan Filipina) dengan komposisi dua sending countries dan dua receiving countries, untuk melakukan pembahasan mengenai prinsip-prinsip dasar, cakupan dan kesamaan pengertian mengenai pekerja migran dan prinsip-prinsip pengaturan hak-haknya dan substansi terkait lainnya.

\section{TUJUAN ASEAN COMMUNITY 2015}

Visi ASEAN 2015 ialah "ASEAN as a concert of Southeast Asian Nations, outward looking, living in peace, stability and prosperity, bonded together in partnership in dynamic development and in a community of caring society" ${ }^{2}$. berdasarkan tujuan pembentukan Komunitas ASEAN 2015 dalam Bali Concord II, ASEAN 1015 terbagi dalam 3 pilar, yaitu :

\section{Komunitas Keamanan ASEAN}

Sejak berdirinya ASEAN, organisasi ini telah memutuskan untuk bekerjasama secara komprehensif di bidang keamanan, ekonomi, dan sosial budaya. Dalam perkembangannya, kerjasama ASEAN lebih banyak dilakukan di bidang ekonomi, sementara kerjasama di bidang politik- keamanan masih belum maksimal akibat adanya persepsi ancaman yang berbeda-beda dan penerapan prinsip- prinsip non- interference serta sovereign equality oleh negara- negara anggota ASEAN.

Komunitas Keamanan ASEAN merupakan sebuah pilar yang fundamental dari komitmen ASEAN dalam mewujudkan Komunitas ASEAN. Pembentukan Komunitas Keamanan ASEAN akan memperkuat ketahanan kawasan dan mendukung penyelesaian konflik secara damai. Terciptanya perdamaian dan stabilitas di kawasan akan menjadi modal bagi proses pembangunan ekonomi dan sosial budaya masyarakat ASEAN.

Komunitas Keamanan ASEAN menganut prinsip keamanan komprehensif yang mengakui saling keterkaitan antar aspek-aspek politik, ekonomi, dan sosial budaya. Komunitas Keamanan ASEAN memberikan mekanisme pencegahan dan penanganan konflik

\footnotetext{
${ }^{2}$ Edi Susanto, Piagam asean;babak baru transformasi organisasi, makalah seminar asean.deplu,unhas
} 
secara damai. Hal ini dilakukan antara lain melalui konsultasi bersama untuk membahas masalah-masalah politik-keamanan kawasan seperti keamanan maritim, perluasan kerjasama pertahanan, serta masalah- masalah keamanan non- tradisional (kejahatan lintas negara, kerusakan lingkungan hidup dan lain-lain).

Dengan derajat kematangan yang ada, ASEAN diharapkan tidak lagi menyembunyikan masalah-masalah dalam negeri yang berdampak pada stabilitas kawasan dengan berlindung pada prinsip- prinsip non- interference.

Komunitas keamanan ASEAN atau ASEAN Security Community (ASC) pada dasarnya dibentuk sebagai upaya untuk menjaga kestabilan kawasan Asia Tenggara. Kestabilan politik dan keamanan akan menunjang sektor ekonomi sehingga mampu menciptakan kawasan yang damai sekaligus makmur. Sebaliknya, iklim ekonomi kawasan yang sehat akan menunjang stabilitas politik dan keamanan karena berkurangnya disparitas ekonomi antar negara. Secara teoritik memang tampak sederhana. Tetapi di tataran realitas, jalan menuju integrasi cukup terjal dan berliku. Ditambah lagi kenyataan bahwa ditinjau dari segi apapun, kawasan Asia Tenggara adalah kawasan yang luar biasa majemuk.

ASEAN sejak lama dikritik bahwa bagaimana mungkin terbentuk sebuah komunitas jika ASEAN masih mengkultuskan prinsip non intervensi dan penghormatan terhadap kedaulatan negara lain. Prinsip ini jelas akan menghambat upaya ASEAN menuju integrasi karena non intervensi mengisyaratkan kedaulatan yang tidak bisa diganggu gugat. Sampai saat ini, kedaulatan bagi negara-negara ASEAN masih dianggap sebagai harga mati. Alhasil, ASEAN masih terjebak dalam eksklusivisme sehingga kehendak bersama yang menjadi syarat mutlak berdirinya sebuah komunitas hanya sebatas retorika belaka. Menandatangani sebuah kesepakatan bersama adalah hal gampang. Tetapi mengimplementasikannya adalah hal lain.

Secara geopolitik, kawasan Asia Tenggara adalah kawasan yang labil. Konflik-konflik yang melibatkan negara-negara anggota ASEAN kebanyakan adalah konflik yang disebabkan karena masalah perbatasan. Klaim wilayah seperti Pulau Sipadan-Ligitan (yang akhirnya menjadi milik sah Malaysia), Blok Ambalat, Camar Bulan, kuil Preah Vihear di perbatasan Thailand-Kamboja, serta sengketa teritorial yang sangat kompleks yaitu klaim kepemilikan atas

Pulau Spratly dan Paracel di Laut Cina Selatan memberikan bukti empiris bahwa masalah kedaulatan masih menjadi isu yang sangat sensitif di kawasan Asia Tenggara. Pembelaan mati-matian terhadap "kepentingan nasional" ini hanya akan mengarah pada egoisme negara 
yang bisa menggerus sense of community antar sesama anggota ASEAN. Sebagai sebuah rezim internasional, ASEAN memiliki instrumen penyelesaian konflik yang berorientasi ke dalam (inward looking). Instrumen penyelesaian konflik dalam wadah ASEAN sebenarnya lebih dari cukup. Pada tahun 1971 ASEAN mendeklarasikan ZOPFAN (Zone of Peace, Freedom and Neutrality). Kemudian pada tahun 1976 ASEAN menandatangani traktat kerjasama yaitu TAC (Treaty of Amity and Cooperation), serta memiliki Dewan Tinggi ASEAN (ASEAN High Council) yang menangani permasalahan antar negara anggota. Untuk menjamin penyelesaian konflik dengan cara damai, ASEAN membentuk ASEAN Regional Forum (ARF) pada tahun $1994^{3}$ yang memungkinkan ASEAN bekerjasama dengan negara di luar ASEAN.

Sebagai instrumen perdamaian, ARF menggunakan pendekatan keamanan kooperatif (cooperative security) dimana keamanan kawasan dicapai bukan dengan instrumen militer, melainkan dengan dialog dan konsultasi. ${ }^{4}$ ARF bertujuan membangun Confidence Building Measure (CBM) supaya pihak-pihak yang terlibat konflik saling menahan diri dan timbul rasa kepercayaan dan pemahaman bersama. Dengan pemikiran semacam ini, ketegangan antar negara bisa dikurangi sehingga bisa mencegah munculnya situasi yang dikenal dengan dilema keamanan (security dilemma).

2. Komunitas Ekonomi ASEAN

Kerjasama ekonomi ASEAN dimulai dengan disahkannya Deklarasi Bangkok tahun 1967 yang bertujuan untuk mempercepat pertumbuhan ekonomi, kemajuan sosial dan pengembangan budaya. Dalam perkembangannya, kerjasama ekonomi ASEAN mengarah kepada pembentukan Komunitas Ekonomi ASEAN yang pelaksanaannya berjalan relatif lebih cepat dibandingkan dengan kerjasama di bidang politik-keamanan dan sosial budaya.

KTT ke- 9 ASEAN di Bali tahun 2003 menghasilkan Bali Concord II yang menegaskan bahwa Komunitas Ekonomi ASEAN (AEC - Asean Economic Community) akan diarahkan kepada pembentukan sebuah integrasi ekonomi kawasan. Pembentukan biaya transaksi perdagangan, memperbaiki fasilitas perdagangan dan bisnis, serta meningkatkan daya saing sektor UKM.Disamping itu, pembentukan AEC juga akan memberikankemudahan dan

\footnotetext{
${ }^{3}$ www.geotimes.co.id.

${ }^{4}$ Hiro Katsumata. 2009. ASEAN's Cooperative Security Enterprise, Norms and Interests In The ASEAN Regional Forum. New York: Palgrave Macmillan.
} 
peningkatan akses pasar intra- ASEAN serta meningkatkan transparansi dan mempercepat penyesuaian peraturan- peraturan dan standardisasi domestik.

Pembentukan Komunitas Ekonomi Asean akan memberikan peluang bagi negara negara anggota ASEAN untuk memperluas cakupan skala ekonomi, mengurangi kemiskinan dan kesenjangan sosial ekonomi, meningkatkan daya tarik sebagai tujuan bagi investor dan wisatawan,mengurangi biaya transaksi perdagangan dan memperbaiki fasilitas perdagangan dan bisnis. Disamping itu, pembentukan Komunitas Ekonomi Asean juga akan memberikan kemudahan dan peningkatan akses pasar intra-ASEAN serta meningkatkan transparansi dan mempercepat penyesuaian peraturan- peraturan dan standardisasi domestik.

Komunitas Ekonomi ASEAN sendiri merupakan sebuah kesepakatan antara anggota ASEAN yang bertujuan untuk menghimpun negara-negara ASEAN ke dalam sebuah pasar tunggal. Konsekuensi logis dari rencana ini adalah adanya pasar bebas (Free Trade Area) antara Negara-negara anggota ASEAN. Bentuk integrasi ekonomi ini direncanakan dimulai pada tanggal 31 Desember 2015. Tujuannya adalah meningkatkan daya saing kawasan, mendorong pertumbuhan ekonomi, mengurangi kemiskinan, dan meningkatkan standar hidup penduduk negara anggota ASEAN.

Sebelum sampai pada kesepakatan pada Cebu Declaration 2007, Komunitas Ekonomi ASEAN melalui berbagai tahapan yang cukup memakan waktu panjang. Dimulai pada Konferensi Tingkat Tinggi (KTT) Ke-2 ASEAN tanggal 15 Desember 1997, di Kuala Lumpur, Malaysia, para pemimpin ASEAN mengesahkan Visi ASEAN 2020. Dengan tujuan antara lain sebagai berikut :

a. Menciptakan Kawasan Ekonomi ASEAN yang stabil, makmur, dan memiliki daya saing tinggi yang ditandai dengan arus lalu lintas barang,jasa-jasa dan investasi yang bebas, pembangunan ekonomi yang merata serta mengurangi kemiskinan dan kesenjangan sosial-ekonomi.

b. Mempercepat liberalisasi perdagangan di bidang jasa.

c. Meningkatkan pergerakan tenaga professional jasa dan lainnya secara bebas di kawasan.

3. Komunitas Sosial Budaya ASEAN

Kerjasama di bidang sosial- budaya menjadi salah satu titik tolak utama untuk meningkatkan integrasi ASEAN melalui terciptanya "a caring and sharing community", yaitu 
sebuah masyarakat ASEAN yang saling peduli dan berbagi. Kerjasama sosial-budaya mencakup kerjasama di bidang kepemudaan, wanita, kepegawaian, penerangan, kebudayaan, pendidikan, ilmu pengetahuan dan teknologi, lingkungan hidup, penanggulangan bencana alam, kesehatan, pembangunan sosial, pengentasan kemiskinan, dan ketenagakerjaan serta Yayasan ASEAN.

Tujuan dibentuknya "Komunitas Sosial dan Budaya ASEAN" untuk memajukan dan mensejahterakan antar negara ASEAN dalam bidang sosial, kebudayaan, pendidikan, ilmu pengetahuan, kesehatan, dan masalah seputar sosial budaya. Selain itu Komunitas Sosial dan Budaya ASEAN ini juga akan menciptakan masyarakat yang beradab, saling menjaga toleransi antar negara ASEAN, saling menghormati, menciptakan rasa persodaraan yang lebih kuat serta menjunjung tinggi rasa kemanusiaan atar negara ASEAN.

Fakta menunjukan, akhir tahun 2015 akan menjadi batas waktu bagi Indonesia untuk memasuki masyarakat ekonomi ASEAN yang membuka batas-batas aturan mengenai pajak, tarif dan bea untuk barang dan jasa di kawasan Asia Tenggara. Hadirnya AEC ini juga akan berpengaruh pada banyak sektor, tidak hanya pada sektor perdagangan bebas untuk berbagai produk barang tetapi juga akan berpengaruh terhadap sektor tenaga kerja dan perkembangan teknologi. Nantinya berbagai negara di ASEAN akan dengan bebas bersaing untuk mengisi sektor tenaga kerja di seluruh negara ASEAN. Bagi negara yang memiliki tenaga kerja dengan kualifikasi pendidikan dan kompetensi yang tinggi, ini akan menjadi peluang untuk melakukan ekspansi tenaga kerja ke negara ASEAN lainnya.

Adapun permasalahan yang terkait dengan tenaga kerja di Indonesia yakni masih bnayaknya tenaga kerja tidak memiliki ketrampilan baik dalam bidang formal maupun informal, serta kurangnya pelatihan yang di berikan sebelum mereka terjun kelapangan. Hal inilah yang membuat tenaga kerja Indonesia menjadi kurang professional. Menjelang Asean Community 2015 Indonesia harus menyiapkan tenaga kerjanya agar lebih siap menghadapi tantangan dan persaingan pada Asean Community 2015. Dengan demikian, Asean Community 2015 merupakan tempat atau wadah yang dapat menciptakan kondisi bangsa dan Negara Indonesia menuju ekonomi yang lebih baik dan bersaing dengan Negara-negara berkembang lainnya.

Pengaruh Asean Community 2015 yakni akan mengakibatkan pasar barang, jasa dan investasi bergerak bebas tanpa batasan geografis. Selain itu, Asean Community 2015 juga pasti akan berdampak langsung pada ketenagakerjaan Indonesia. Secara teoritis, liberalisasi 
dalam pasar barang, jasa, modal dan tenagakerja akan meningkatkan produktivitas tenaga kerja, karena akan menciptakan kondisi yang mendorong perusahaan untuk mengalokasikan sumber-sumber daya secara lebih efisian. ${ }^{5}$ Adanya mobilitas tenaga kerja yang tanpa batas, tentu akan membuat kesempatan kerja bagi angkatan kerja semakin luas dengan cakupan wilayah yang luas pula.

Dalam hal ini, tenaga kerja bisa bebas memilih jenis pekerjaan sesuai dengan yang mereka inginkan dan perusahaan juga dapat memilih tenaga kerja yang sesuai dengan spesifikasi dan kualifikasi yang mereka tentukan. Namun, hal tersebut jangan sampai membuat masyarakat Indonesia bersenang dulu karena justru ketika pasar barang dan jasa itu dimulai tanpa kesiapan sumber daya manusia yang berkualitas kita hanya akan menjadi penonton kesuksesan dinegeri sendiri. Seperti yang saat ini terjadi, jumlah pekerja migran yang besar dari Indonesia cenderung didominasii oleh pekerja dengan keahlian rendah (lowskilled). Oleh karena itu, adanya Asean Community 2015 ini menuntut tenaga kerja Indonesia mempunya keahlian yang lebih dari rata-rata agar bisa bersaing dengan tenaga kerja asing dari negara-negara tetangga dengan cara perbaikan kualitas dari tenaga kerja Indonesia.

Pendekatan multilateralisme dan regionalisme Indonesia diharapkan mampu memberikan kontribusi dalam upaya mengembangkan semangat intra kawasan dalam mengimbangi sikap unilateralisme. Untuk itulah, pada tataran regional ASEAN 2015, setidaknya yang perlu dipersiapkan bangsa Indonesia adalah kesetaraan (equity), keamanan (security) dan keberlanjutan (sustainability). Selain permasalahan daya saing, hingga hari ini bangsa Indonesia masih dihadapkan pada sejumlah permasalahan pembangunan yang mendasar seperti meluasnya kemiskinan, masih terdapatnya potensi konflik sosial, terbatasnya akses masyarakat ke layanan dasar (seperti layanan pangan, kesehatan, dan obat-obatan, energi, transportasi, informasi dan komunikasi, dan rasa aman), serta terdegradasinya lingkungan hidup.

Di samping itu, kemampuan ilmu pengetahuan dan teknologi (iptek) bangsa Indonesia juga masih sangat terbatas, sehingga iptek bangsa Indonesia belum mempunyai peranan yang berarti dalam penyelesaian berbagai permasalahan pembangunan tersebut. Hal ini berimplikasi pada tingginya tingkat ketergantungan berbagai kegiatan pembangunan dengan negara lain. Kondisi tersebut menghadirkan suatu tantangan tersendiri bagi bangsa Indonesia

\footnotetext{
${ }^{5}$ Sugiyono, Metode Penelitian Administrasi, Bandung: CV Allfabeta, 2010
} 
untuk membangun SDM bangsa, dan di sisi lain meningkatkan peranan SDM yang berkualitas dalam menjawab permasalahan pembangunan.

Indonesia tidak dapat membangun daya saing nasional dalam waktu sekejap sehingga perlu tahapan dengan melakukan transformasi di semua bidang. Untuk itulah sangat tepat jika visi Indonesia 2020 adalah wujudnya masyarakat Indonesia yang religius, manusiawi, bersatu, demokratis, adil, sejahtera, maju, mandiri, serta baik dan bersih dalam penyelenggaraan negara. Bagi bangsa Indonesia yang berdaulat dan menganut prinsip bebasaktif, dibutuhkan suatu strategi peningkatan daya saing industri yang mengombinasikan prinsip interdependensi (melalui impor) dan independensi (melalui penguasaan iptek) sehingga daya saing bangsa dapat dicapai dalam kerangka menuju ASEAN Community 2015.

Diplomasi juga diarahkan untuk mendukung upaya peningkatan kinerja ekspor, peningkatan arus investasi dan wisatawan, penyelesaian masalah hutang luar negeri, perluasan kesempatan kerja bagi TKI di luar negeri, pengentasan kemiskinan melalui pencapaian Millennium Development Goals, dan peningkatan kerja sama teknik antarnegara.

Selain itu, persoalan-persoalan seperti penegakkan hukum, terorisme masalah korupsi, pengelolaan dan pelestarian lingkungan hidup, pengentasan rakyat dari kemiskinan melalui pencapaian Millennium Development Goals, pemajuan dan penghormatan hak asasi manusia (HAM), penyelesaian wilayah perbatasan, tuntutan akan kualitas koordinasi penanganan, pelayanan dan perlindungan terhadap WNI di luar negeri, akan tetap mewarnai dinamika pelaksanaan politik luar negeri dalam rangka kerjasama internasional.

Liberalisasi dalam perdagangan barang, jasa, investasi, dan mobilitas faktor produksi tenaga Kerja akan berdampak pada kondisi ketenagakerjaan. Secara teoritis, liberalisasi dalam faktor di atas akan meningkatkan produktivitas tenaga kerja, karena akan menciptakan kondisi yang mendorong perusahaan untuk mengalokasikan sumber-sumber daya secara lebih efisien (dampak alokasi). Dihapusnya hambatan dalam mobilitas tenaga kerja akan membuka kesempatan pada para pekerja untuk mencari pekerjaan yang dianggap paling sesuai dengan keahlian yang dimiliki. Di sisi lain, pengusaha juga memperoleh kesempatan untuk mempekerjakan tenaga kerja yang dianggap paling cocok. Peningkatan produktivitas tenaga kerja ini pada akhirnya akan meningkatkan permintaan terhadap tenaga kerja dan selanjutnya juga menaikkan upah tenaga kerja. Meskipun demikian, bukti empiris terkait dengan dampak integrasi ekonomi terhadap kondisi ketenagakerjaan. 


\section{KONDISI TENAGA KERJA}

Kawasan ASEAN merupakan satu diantara wilayah yang strategis dalam penyediaan lapangan pekerjaan, khusunya pada program Asean Community 2015 yang akan diimplementasikan pada tahun 2015. Sebagai satu diantara pilar pendukung dalam pembentukan Asean Community 2015, aliran tenaga kerja terampil yang menjadi satu diantara topik yang menjuadi fokus perhatian utama. Terbentuknya Asean Community 2015 akan memberikan peluang dan harapan sekaligus tantangan bagi masa depan bagi pencari kerja. Asean Community 2015 akan menjadikan ASEAN seperti suatu negara besar yang akan memberikan kesempatan seluas-luasnya bagi para pekerja untuk mengisi lowongan kerja yang tersedia, keluar dan masuk dari suatu wilayah negara lain tanpa hambatan. Mereka akan mempunyai kebebasan dan kemudahan untuk memilih lokasi apa saja yang sesuai dan menguntungkan.

Dalam Asean Community 2015 yang menjadi tujuan akhir proses intergrasi ekonomi regional ASEAN adalah terdapatnya aliran bebas yang terjadi baik dipasar produk maupun dipasar faktor-faktor produksi. Untuk menjamin terwujudnya Asean Community 2015 tersebut, telah disusun suatu kerangka kerja yang berfungsi sebagai pedoman bagi setiap negara anggota dalam mempersiapkan diri.Namun demikian, pembahasan tenaga kerja tersebut dibatasi dalam pengaturan khusus tenaga kerja terampil (skilled labour) dan tidak terdapat pembahasan mengenai tenaga kerja tidak terampil (unskilled labour). Tenaga kerja terampil (skilled labour) dapat diartikan pekerja yang memiliki keterampilan khusus, pengetahuan, dan keahlian di bidangnya. Selain itu, tenaga kerja terampil juga dapat diartikan sebagai tenaga kerja berasal dari lulusan perguruan tinggi, akademi, atau sekolah teknik serta berdasarkan pengalaman kerja sebelumnya. Pembahasan mengenai kerja tidak terampil (unskilled labour) biasanya akan dibicarakan secara bilateral karena merupakan isu yang sangat sensitif.

Dalam perkembangan ekonomi Indonesia menghadapi Asean Community 2015 terutama pada bidang tenaga kerja pada potensi saat ini negara Indonesia adalah negara yang memiliki sumber daya manusia tertinggi di Asean dan memberikan pengaruh yang besar bagi terwujudnya Asean Community 2015 mendatang, namun untuk menghadapinya dibutuhkan berbagai persiapan untuk meningkatkan ketrampilan bagi tenaga kerja Indonesia.Menuju Asean Community 2015 akan terjadi migrasi pada tenaga kerja pada sektor-sektor formal maupun informal yang memiliki daya saing tinggi pada kualitas sumber daya manusianya. Oleh sebab itu, Indonesia harus mempersiapkan semenjak dini sumber daya manusianya agar memiliki harga jual yang dapat bersaing dengan tenaga kerja negara Asean lainnya. 
Perkembangan saat ini yang terjadi pada tenaga kerja Indonesia tidak memiliki ketrampilan serta pengetahuan pada saat dilapangan pekerjaan, perlu diperhatikan serta ditingkatkan melalui pelatihan-pelatihan pada masa karatina sebelum tenaga kerja di pekerjakan. Pemerintah harus terus meningkatkan pertumbuhan tenaga kerja yang memiliki ketrampilan melalui pendidikan dan pelatihan sehingga meningkatkan kualifikasi dan kualitas sumber daya manusia di Indonesia. Selain itu, pemerintah harus lebih tegas dalam membuat kebijakan untuk tenaga kerja Indonesia serta pengawasan yang lebih cermat atas kendala-kendala yang terjadi selama ini dalam ketenaga kerjaan Indonesia baik di dalam negeri maupun di luar negeri.

Kondisi lain ketenagakerjaan berupa ke-tidakseimbangan di dalam penyebaran tenaga kerja di antara pulau-pulau di Indonesia sehingga mengakibatkan pemanfaatan tenaga kerja maupun sumber-sumber alam menjadi kurang optimal dan kurang terarah. Ditambah lagi kondisi ketidakseimbangan lain dalam hal pemenuhan kualifikasi yang dipersyaratkan tuntutan dunia usaha.

Adanya ketidak sesuaian antara jenis tenaga kerja terdidik yang diperlukan untuk mengisi lapangan kerja yang terbuka dalam pembangunan dengan jenis-jenis tenaga kerja yang dihasilkan oleh sistem pendidikan, menimbulkan gejala pengangguran di kalangan tenaga terdidik. Pasar tenaga kerja belum mampu menyerap tenaga kerja secara efektif mengakibatkan banyak tenaga kerja yang tidak termanfaatkan secara optimal untuk kepentingan pembangunan.

Masalah lain yang terjadi pada sektor ketenagakerjaan antara lain tuntutan kenaikan upah yang signifikan dalam konteks UMR (Upah Minimum Regional), isu pekerjaan yang bersifat outsourcing, isu produktivitas, namun di sisi lain perusahaan masih kesulitan mencari tenaga kerja yang sesuai kebutuhan. Terjadi pula penurunan permintaan tenaga kerja pada sektor padat karya di dalam negeri dan masih menyisakan pekerjaan rumah bagi Tenaga Kerja Indonesia di luar negeri.Beberapa permasalahan tenaga kerja di luar negeri lebih banyak disebabkan ketidakhadiran negara dalam advokasi dan perlindungan tenaga kerja.

Permasalahan terkait individu tenaga kerja yaitu pendidikan rendah, tidak memiliki kompetensi, kemiskinan, menjadi andalan ekonomi utama keluarga dan lain sebagainya. Permasalahan pelaku usaha terkait akreditas dan sertifikasi perusahaan yang mengirimkan jasa tenaga kerja, fasilitas pelatihan yang minim dan belum terstandar, tingkat keuntungan yang tinggi dalam pengiriman Tenaga Kerja Indonesia (TKI) (economy driven), berorientasi pada pemenuhan kuota pengiriman, penempatan tenaga kerja dilihat sebagai industri, dan lain sebagainya. Dari sisi regulasi dan kebijakan, persoalan yang terjadi adalah masih tumpang tindihnya peraturan Tenaga 
Kerja Indonesia, belum memadainya kebijakan yang mengatur perlindungan dan asuransi TKI; belum adanya lembaga tunggal yang bertanggung jawab penuh terhadap permasalahan TKI, serta belum tegasnya sanksi hukum yang berkaitan dengan pelanggaran-pelanggaran ketenagakerjaan.

\section{Pengaruh Asean Community 2015 bagi tenaga kerja yang tidak memiliki ketrampilan (unskill) di Indonesia}

Pada tahun 2015 mendatang Indonesia akan menghadapi Asean Community yang akan berlaku seluruh Asean kerjasama regional yang terjalin khususnya pada bidang ekonomi akan menjadi tujuan utama pada Asean Community 2015, terutama pada bidang jasa yaitu tenaga kerja menjadi prioritas utama dalam menjual jasa. Tenaga kerja memiliki pengaruh besar di Asean Community 2015.

Pengaruh bagi tenaga kerja Indonesia yang tidak memiliki ketrampilan (unskill) sangat besar pada Asean community 2015 mendatang akan terjadi pertukaran atau pertukaran tenaga kerja antar Negara untuk bekerja di Negara-negara yang tergabung pada Asean Community,persaingan ini akan berpengaruh bagi tenaga kerja yang tidak memiliki ketrampilan(unskill)di Indonesia,tenaga kerja ini akan mengalami banyak kesulitan serta tidak dapat bersaing dikarenakan tidak memiliki ketrampilan yang dapat menjadi standarisasi syarat dalam bidang ketenagakerjaan baik formal maupun informal,pengaruh yang menjadi beban moral bagi pemerintah Indonesia saat ini adalah tenaga kerja yang tidak memiliki ketrampilan (unskill) dalam hal ini pemerintah harus lebih memberikan pelatihan ketrampilan bagi tenaga kerja yang tidak memiliki ketrampilan serta memberikan pelatihan bagi mereka agar bisa bersaing menghadapi tenaga kerja dari negara lainnya.

\section{Kebijakan pemerintah Indonesia dalam bidang ketenagakerjaan.}

Badan Nasional Penempatan dan Perlindungan Tenaga Kerja Indonesia (disingkat BNP2TKI) adalah sebuah Lembaga Pemerintah Non Departemen di Indonesia yang mempunyai fungsi pelaksanaan kebijakan di bidang penempatan dan perlindungan Tenaga Kerja Indonesia di luar negeri secara terkoordinasi dan terintegrasi. Lembaga ini dibentuk berdasarkan Peraturan Presiden Nomor 81 Tahun 2006.

Tugas pokok BNP2TKI adalah: 
1. Melakukan penempatan atas dasar perjanjian secara tertulis antara Pemerintah dengan Pemerintah negara Pengguna TKI atau Pengguna berbadan hukum di negara tujuan penempatan

2. Memberikan pelayanan, mengkoordinasikan, dan melakukan pengawasan mengenai: dokumen; pembekalan akhir pemberangkatan (PAP);

Penyelesaian masalah; sumber-sumber, pembiayaan; pemberangkatan sampai pemulangan; peningkatan kualitas calon TKI; informasi; kualitas pelaksana penempatan TKI; dan peningkatan kesejahteraan TKI dan keluarganya. Keanggotaan BNP2TKI terdiri dari wakil-wakil instansi Pemerintah terkait. Dalam melaksanakan tugasnya, BNP2TKI dapat melibatkan tenagatenaga profesional.

Badan Nasional Penempatan dan Perlindungan Tenaga Kerja Indonesia merupakan lembaga Pemerintah Non Kementerian yang bertanggung jawab kepada Presiden (pasal 94 ayat 3, UU 39/2004).Pelaksanaan kebijakan dibidang penempatan dan perlindungan tenaga kerja Indonesia di luar negeri secara terkoordinasi dan terintegrasi (pasal 95 ayat 1 UU No. 39/2004).

\section{Langkah-Langkah Pemerintah Indonesia dalam menghadapi Asean Community 2015 bagi tenaga kerja yang tidak memiliki ketrampilan(unskill).}

ASEAN Community pada tahun 2015 nantinya menjadi babak baru bagi perkembangan pada tiga sektor, antara lain disektor Perekonomian, Keamanan, dan Sosial Budaya antar negara anggota ASEAN. Negara-negara khususnya di kawasan Asia Tenggara memberikan harapan akan prospek dan peluang bagi kerjasama Ekonomi, Keamanan dan Sosial Budaya, Pengaruh Asean Community 2015 yakni akan mengakibatkan Liberalisasi dalam perdagangan barang, jasa, investasi, dan mobilitas faktor produksi tenaga kerja akan berdampak pada kondisi ketenagakerjaan, pasar barang, jasa dan investasi bergerak bebas tanpa batasan geografis. Selain itu, Asean Community 2015 juga pasti akan berdampak langsung pada ketenagakerjaan Indonesia.

Berdasarkan dampak tersebut,maka pemerintah melakukan langkah-langkah dalam menghadapi Asean Community 2015 tersebut adapun langkah-langkahnya adalah sebagai berikut:

1. Pusat Penelitian dan Pengembangan (Litbang) Ketenagakerjaan Kementerian Tenaga Kerja dan Transmigrasi (Kemnakertrans) telah menyusun draft Arah Kebijakan Bidang 
Ketenagakerjaan 2014-2019. Pertama, isi draft tersebut adalah menjadikan pelatihan kerja sebagai pekerjaan nasional, dengan dasar hukum setingkat Undang-undang. Hal ini tentu saja harus diimbangi dengan anggaran yang memadai agar dapat menghasilkan lulusan yang memadai, baik kuantitas maupun kualitasnya. Kedua, yakni mengenai penempatan tenaga kerja pada pekerjaan-pekerjaan layak, anti diskriminasi dalam bentuk apapun, termasuk penempatan tenagakerja Indonesia (TKI) keluar negeri dengan mengedepankan terjaganya martabat bangsa dan kemanfaatan. Ketiga, menciptakan hubungan industrial yang harmonis, dengan melindungi pengusaha tanpa mengabaikan kesejahteraan pekerja dalam prinsip egalitarian (flexicurity), diikuti dengan pengembangan budaya perusahaan, budaya pekerja, dan budaya pemerintah. Keempat, merevitalisasi fungsi pengawasan ketenagakerjaan melalui pengawasan ketenagakerjaan yang sentralistik, didukung oleh pengawas ketenagakerjaan yang kompeten dan profesional.

2. Kegiatan pengaman dan pengawasan penempatan dan perlindungan tenaga kerja Indonesia tahun 2013 oleh badan penempatan dan perlindungan tenaga kerja Indonesia(bnp2tki) seperti berikut

- Pengamanan wilayah perbatasan

- Pengawasan tehadap PPTKIS

- Pemulangan calon tenaga kerja Indonesia non procedural.

\section{Undang-undang no.13 tahun 2003}

Salah satu implementasi kebijakan pemerintah yang akan penulis bahas dalam tulisan ini yakni kebijakan tentang ketenagakerjaan. Kebijakan tentang ketenagakerjaan dituangkan dalam Undang-Undang Tenaga Kerja No. 13 Tahun 2003. Adapun mengenai perencanaan tenaga kerja dan informasi ketenagakerjaan diatur dalam bab IV UU No. 13 Tahun 2003. Berikut akan penulis paparkan mengenai pasal -pasal beserta isinya dalam bab IV UU No. 13 Tahun 2003.

\section{Undang-undang no.39 tahun 2004}

Mengenai penempatan,pengawasan serta perlindungan tenaga kerja Indonesia.

\section{KESIMPULAN}

Menjelang 2015 indonesia akan menghadapi globalisasi ekonomi dalam Tenaga Kerja Indonesia bukan lagi sebuah fenomena migrasi penduduk keluar negeri untuk bekerja, tetapi sesudah menjadi sebuah tren yang menjadikan karakter bangsa ini yang sering melakukan 
pengiriman tenaga kerjanya keluar negeri.Hal ini dikarenakan, lapangan pekerjaan di Indonesia yang sangat terbatas terutama bagi masyarakat yang berpendidikan rendah, mereka rela keluar dari negerinya untuk mengadu nasib dengan tenaga kerja lainnya.

Pada Asean Community 2015 mendatang akan terjadi pasar bebas dalam bidang barang dan jasa,pada bidang jasa yaitu tenaga kerja akan adanya persaingan dalam kualitas serta kemampuan pada tenaga kerja dalam pendidikan,ketrampilan serta kekuatan mental untuk dapat berkompetisi pada Asean Community 2015 mendatang.

Permasalahan terkait individu tenaga kerja yaitu pendidikan rendah, tidak memiliki kompetensi, kemiskinan, menjadi andalan ekonomi utama keluarga dan lain sebagainya. Permasalahan pelaku usaha terkait akreditas dan sertifikasi perusahaan yang mengirimkan jasa tenaga kerja, fasilitas pelatihan yang minim dan belum terstandar, tingkat keuntungan yang tinggi dalam pengiriman Tenaga Kerja Indonesia (TKI) (economy driven), berorientasi pada pemenuhan kuota pengiriman, penempatan tenaga kerja dilihat sebagai industri, dan lain sebagainya. Dari sisi regulasi dan kebijakan, persoalan yang terjadi adalah masih tumpang tindihnya peraturan Tenaga Kerja Indonesia, belum memadainya kebijakan yang mengatur perlindungan dan asuransi TKI; belum adanya lembaga tunggal yang bertanggung jawab penuh terhadap permasalahan TKI, serta belum tegasnya sanksi hukum yang berkaitan dengan pelanggaran-pelanggaran ketenagakerjaan.

Kebijakan pemerintah yang telah dibuat dalam peraturan undang-undang no.13 tahun 2003 dan undang-undang no.39 tahun 2004 yang mengatur ketenagakerjaan Indonesia agar tenaga kerja Indonesia dapat memiliki hak serta kewajiban yang sesuai, agar tenaga kerja Indonesia memperoleh keadilankesetaraan dengan tenaga kerja asing lainnya.

Langkah-langkah pemerintah dengan membuat program ketrampilan bagi tenaga kerja yang tidak memiliki ketrampilan,merupakan langkah utama pemerintah dalam meningkatkan kualitas tenaga kerja Indonesia serta peran pemerintah mengawasi dan melindungi tenaga kerja Indonesia agar dapatbersaing/berkompetisi dengan tenaga kerja asing di Asean Community 2015.

\section{DAFTAR PUSTAKA}

Morgenthau,H.J.1951.in defense of the national interest:a critical examination of American foreign policy, New York: university press of America.

Anwar,mohammad arsjad dkk.1995.sumber daya teknologi,dan pembangunan,Jakarta: PT.Gramedia Pustaka 
Hiro Katsumata. 2009. ASEAN's Cooperative Security Enterprise, Norms and Interests In The ASEAN Regional Forum. New York: Palgrave Macmillan.

Mohtar mas'oed.1994.Ilmu hubungan internasional:disiplin dan metodologi,Jakarta:pustaka LP3ES

Jacson,Robert dan Georg Sorensen.2005.Pengantar studi hubungan internasional.(diterjemahkan oleh:DadanSuryadipura).Yogyakarta:Pustaka Pelajar.

Dugis,Vinsensius dan Wardhani,Baiq.2012.Liberalisme,Teori hubungan internasional,Surabaya: Departemen hubungan internasional,universitas Airlangga.

Soepatro, 1997, Hubungan Internasional Sistem, Interaksi dan Perilaku, Jakarta : PT Raja Grafindo Persada,

Sugiyono.2006,Metode Penelitian Administrasi,Bandung: Penerbit CV Allfabeta

Susanto, Edi, Piagam asean;babak baru transformasi organisasi, makalah seminar asean.deplu,unhas

Undang-undang Republik Indonesia no.39 tahun 2004 tentang penempatan dan perlindungan tenaga kerja luar negeri, Bandung: Penerbit Citra Umbara

www.geotimes.co.id.

http//id.wikipedia.org//wiki/wawasan_2020_asean 